\title{
No bicentenario do nacemento de Marcial Valladares: unha cronoloxía da súa biobibliografía
}

\author{
In the Bicentenary of the Birth of Marcial Valladares: \\ A Chronology of his Biobibliography
}

\author{
Xosé A. Fernández Salgado \\ Universidade de Vigo \\ xsalgado@uvigo.es \\ Recibido: noviembre 2020. Aceptado: enero 2021
}

\begin{abstract}
Resumo: Este traballo quere conmemorar o bicentenario do nacemento de Marcial Valladares (1821-1903), un autor fundamental do Rexurdimento galego que se distingue por unha obra pioneira, prolífica e poliédrica que conxuga o literario, o lingüístico e o folclórico. Con este obxectivo, realizamos un relato cronolóxico da súa biobibliografía, resultado de revisar, sistematizar e harmonizar os datos de traballos xa existentes sobre o escritor e lingüista e doutros novos procedentes do rastrexo feito nas páxinas da prensa do século XIX e XX.
\end{abstract}

Palabras chave: historia da lingua galega, historia da literatura galega, Rexurdimento, Marcial Valladares, biografía.

\begin{abstract}
This paper wants to commemorate the bicentenary of the birth of Marcial Valladares (1821-1903), a key author of the 19th-century Galician Revival that stood out for his pioneering, prolific and multifaceted work, combining the literary, linguistic and the folcloric. To this aim, a chronological account of his life is produced by reviewing, systematizing and harmonizing the existing data of works about the writer and linguist and further information from the pages of the 19th and 20th-century press.
\end{abstract}

Keywords: History of Galician language, History of the Galician literature, 19th century Galician Revival, Marcial Valladares, Biography. 


\section{I.- POR QUE CELEBRAR A MARCIAL VALLADARES?}

Dous séculos despois do seu nacemento, Marcial Valladares (1821-1903) merece seguir sendo lembrado na historia da lingua e literatura galegas por ser no contexto do Rexurdimento galego do século XIX artífice dunha prolífica e pioneira obra na que conflúen os estudos lingüísticos, a creación literaria e a colección folclórica; e aínda máis, pois como erudito que era cultivou tamén disciplinas como a música, a historia, a botánica, o debuxo ou a tradución e, como xestor da Administración pública, enfrontou cuestións de economía, estatística, educación ou agricultura.

A súa produción como escritor e lingüista abrangue un longo período de tempo, que se inicia arredor de 1840 e acada os albores do século XX. Neses máis de sesenta anos a súa obra e a súa ideoloxía reciben e participan das influencias dos grandes movementos estéticos, culturais e políticos que percorren a Europa, a España e a Galicia do seu tempo. Nomeadamente beben do ideario do Romanticismo francés de Lamartine, Chateaubriand e B. de SaintPierre, e do Socialismo utópico de Saint-Simon e Fourier ou da Democracia cristiá, cuxas ideas se debatían na Academia Literaria santiaguesa e na prensa xurdida arredor dela cando Valladares era universitario. Pero é tamén debedora da tendencia «Costumista» española de Larra ou Mesonero Romanos e mais da revalorización de todo o «popular» que se produce co nacemento do «FolkLore» como ciencia por mediados do século. E, certamente, no contexto da Galicia decimonónica, a obra valladariana asume o galeguismo dos chamados primeiramente «provincialistas» (defensores da provincia única, Galicia como unidade, fronte á división provincial de 1833), que formulan Faraldo ou Neira de Mosquera, e máis tarde do «rexionalismo» (soberanía para a rexión fronte ao poder central), con Murguía liderando a liña máis progresista e Brañas a máis tradicionalista e conservadora. Este nacente galeguismo, entre outras cuestións, propuñan a toma de consciencia do que era singular de Galicia, rescatar a autoestima de ser galego e amosar unha imaxe de Galicia fértil en talento e orgullosa de si, da súa cultura, dos seus costumes e tradicións, da súa lingua e literatura, da súa historia, da súa ciencia... Todo iso desembocaría no que daquela se chamou «renacemento» ou «renacenza» e posteriormente «Rexurdimento».

Neste empeño de reconstrución identitaria é cando se redactan as primeiras Historias de Galicia: a de Verea Aguiar (1838), Martínez Paadín (1849), Vicetto (1865) e Murguía (1865); cando se impulsa o cultivo literario da lingua vernácula: os primeiros poemas líricos en galego son dos primeiros anos da década de 1840 e levan a sinatura de A. de la Iglesia, Añón, Pintos, Camino e do propio Valladares; cando se redactan os primeiros dicionarios galegos: o de Rodríguez (1863), Cuveiro (1876) e o do mesmo Valladares (1884), e tamén as primeiras gramáticas: a de Mirás (1864), Saco (1868) e, outra vez, a de Valladares (1892); e mais cando se realizan as primeiras recolleitas de cantigas: a de Valladares, López de la Vega, Rosalía de Castro ou Casal Lois, que teñen lugar nos primeiros anos da década de 1860. Os problemas de Galicia e o uso do galego irán tamén adquirindo presenza e notoriedade cada vez máis na prensa da época, en cabeceiras tan significativas como El Recreo Compostelano ou El Idólatra de Galicia, nos primeiros anos da década de 1840; El Eco de Galicia, 
La Oliva ou El Miño na década de 1850; Galicia Revista Universal, na de 1860; El Heraldo Gallego na de 1870; La Ilustración Gallega y Asturiana a principios da de 1880 e a Galicia. Revista Regional contra finais; a Revista Gallega, xa nos anos derradeiros do século; e tamén na emigración, con xornais como $E l$ Eco de Galicia, tanto o editado na Habana como en Bos Aires. Nacen así mesmo os primeiros semanarios monolingües en galego, como $O$ Vello do Pico Sagro (1860), O Tío Marcos (1876-1880, 1883-1889), O Galiciano (18841888) ou A Monteira (1889-1890). Moitas destas publicacións acollerán nas súas páxinas colaboracións de Valladares.

Así pois, Marcial Valladares merece ser celebrado porque foi un dos homes daquela elite intelectual que máis entusiasmo puxo en traballar polas cousas da súa terra e, como acabamos de ver, o seu nome aparece mencionado en varias actividades. Como poeta, as súas primeiras e pioneiras composicións poéticas en galego tipicamente románticas da década de 1840 deixarán paso a outras de carácter costumista e satírico durante a década de 1870 e os primeiros anos da de 1880; ademais, como narrador, será o inaugurador do xénero novelístico en galego en 1870. Como lingüista, destacarase primeiro como lexicógrafo cun dicionario publicado en 1884, ao que engadirá varios apéndices, e logo como gramático e interesado na codificación escrita do galego cun texto gramatical de 1892 e varios artigos sobre ortografía publicados na prensa do momento. Finalmente, como colector de folclore, levou a cabo una completa e variada recollida de mostras populares: cantigas, refráns, contos, adiviñas..., moi gorentosa para outros estudosos do folclore que axiña solicitaron a súa colaboración.

A este inxente labor aínda habería que lle axuntar a redacción dunha crónica histórica de Zamora, un catálogo de árbores, varias novelas en castelán, os artigos para o dicionario xeográfico de Madoz, libros de viaxes... e, certamente, as súas autógrafas e voluminosas Memorias de familia que se revelan, alén de guía para a súa biografía e a da familia, como un extraordinario documento antropolóxico e histórico do vivir cotián dunha familia culta e acomodada do rural galego, pero que debe tamén interactuar co mundo burgués vilego de Santiago, Pontevedra ou Zamora por mor da posición que desempeñan algúns membros da familia no novo aparato político-administrativo provincial do Estado da época isabelina.

Este traballo quere conmemorar o bicentenario do nacemento de Marcial Valladares e para iso optamos por realizar un percorrido cronolóxico por aqueles episodios que dun xeito ou doutro axudan a comprender mellor a súa personalidade e, xa que logo, as súas contribucións lingüísticas, literarias e folclóricas ao Rexurdimento do século XIX. Para o relato desta viaxe biobibliográfica partimos dos traballos de Fernández Salgado (2002, 2005), que non obstante agora se revisan e actualizan nalgúns puntos tras novas investigacións nas páxinas da prensa da época e a publicación de novos estudos entre os que cómpre destacar o titulado O legado dos Valladares de Vilancosta de Ferreirós Espinosa (2018). Esta magna obra contén unha valiosísima información sobre a familia alén da edición de poemas, cartas e outros documentos tanto de José Dionisio Valladares coma dos seus fillos e descendentes Marcial, Sergio, Avelina e Luísa Valladares e mais de Laurentino e José Espinosa. No «Anexo» final 
deste traballo engádese tamén unha relación de referencias ordenadas cronoloxicamente doutros autores que coma nós tamén se interesaron pola vida de Marcial Valladares. Para unha relación completa dos títulos que conforman a bibliografía valladariana remitimos ao traballo de Fernández Salgado (2018).

\section{II.- UNHA CRONOLOXÍA DA SÚA VIDA E OBRA}

1821: Marcial Valladares Núñez nace o 14 de xuño na «casa grande» de Vilancosta, na Ulla (Berres-A Estrada), fillo de don José Dionisio Valladares, coñecido como «O Intendente», avogado, militar e político, ilustrado e culto; e dona Asunción Núñez, filla dun avogado con despacho en Vilancosta e Santiago. É bautizado cos nomes de Marcial, Ramón, Josef, María del Pilar, aínda que nas súas obras máis importantes só utilizou o primeiro nome seguido habitualmente dos dous apelidos. Nos seus manuscritos tamén asinou coas siglas M.V.N. e M.V. O nome viñéralle orixinado da lembranza da batalla contra os franceses de San Marcial, por terras vascas, na que participara seu pai. Era o terceiro fillo da familia, o primeiro home; os restantes irmáns que lograron sobrevivir os primeiros meses de vida levaban os nomes de Petra, Jacoba, Sergio, Avelina, Luísa, Segunda e Isabel. Sergio e Avelina tamén serán escritores.

1823: A súa nenez decorre no casal de Vilancosta no seo dunha familia acomodada, de vivir fidalgo, culta, amiga das letras e da música, ademais de moi relixiosa e gardadora dos valores tradicionais. Foron tamén os Valladares unha familia de referencia nas terras da Ulla e Tabeirós para os diferentes gobernos políticos e para quen precisou de información erudita de calquera tipo sobre esas comarcas. O pai, home de moral recta e fortes conviccións relixiosas, sentiu unha especial preocupación pola educación dos seus fillos e por transmitirlles eses mesmos valores, na que tamén participaron a nai e as tías maternas sobre todo no referido ás prácticas relixiosas. Diariamente facía acudir a Vilancosta un mestre para as clases das primeiras letras, as cales co tempo serían para Marcial e Sergio tamén de latín e de gramática castelá, impartidas estas polo cura da parroquia.

1833: En outubro, feitos os 12 anos, trasládase co seu irmán Sergio, un curmán e unha tía materna a Compostela para comezar os cursos preparatorios de Filosofía con vistas a nun futuro facer a carreira de Leis. Vivirán nunha casa arrendada da rúa da Senra e logo noutra do Poxigo. Santiago amósaselle a Marcial como un espazo vilego e burgués totalmente novidoso, afeito como estaba el e o seu irmán á vida nunha aldea da Ulla no século XIX.

1835: Estuda o terceiro ano de Filosofía no Seminario Conciliar de Ourense, cidade a onde o pai fora destinado como Secretario do Goberno civil.

1839: Pasa as vacacións de verán de estudante coa familia en Pontevedra, onde o pai exercía de Intendente e Xefe político da provincia. Durante o verán recibirá a visita do seu amigo José $\mathrm{M}^{\mathrm{a}}$ Gil, poeta e médico que dirixía o 
xornal santiagués Semanario Instructivo; con el manterá a familia unha delongada amizade e correspondencia. En setembro alístase un mes de voluntario en Pontevedra na compañía de «Nacionales movilizados»e como soldado participará nalgunha escaramuza contra faccións carlistas. Deste tempo, son as súas primeiras composicións poéticas, ao principio en castelán.

1840: En xullo obtén o título de Bacharel en Leis pola universidade compostelá. Durante o verán pasa as vacacións coa familia en Lugo, a onde o pai fora trasladado como Intendente. Alí dedicarase a copiar mapas e tomar leccións de música.

1841: Realiza os primeiros apuntamentos de danzas e melodías populares nalgunhas romarías da Ulla, como as de Gundián ou do Sacramento en Ortigueira que se celebraban xa nos remates do verán.

1842: En xullo licénciase en Xurisprudencia pola Universidade de Santiago. Dá comezo a un caderno de poemas titulado Juguetes poéticos cunha poesía inicial en castelán titulada «Brindis», caderno que clausuraría definitivamente en 1862 cos versos relixiosos «El pecador contrito», tamén en castelán. Deste ano data tamén o principio do poemario Enredos poéticos. Nestes manuscritos recolleranse a súas primeiras poesías en galego, aínda que de título castelán: «El y Ella» ou «Cantiga á un cazador». Deste ano é a primeira publicación súa de que temos constancia, o poema amoroso en castelán que comeza «Recoge, recoge», editado no xornal pontevedrés Las Musas del Lérez que dirixe Cuveiro.

1843: En Compostela, toma clases de francés e asiste á Cátedra de Historia natural do doutor Casares. Nestes anos rexorde con forza na cidade, ao abeiro dos ideais do Romanticismo, a Academia Literaria que integran un animoso grupo de estudantes liberais e algún profesor, que conformaría a primeira xeración romántica chamada logo dos «provincialistas» - Neira de Mosquera, os irmáns Faraldo, Díaz de Robles, Añón, os irmáns Camino, os Rúa Figueroa...- á cal non é allea Valladares.

No verán comeza a colaborar co pai na redacción de artigos e informes sobre as terras de Lalín e Tabeirós para o Diccionario xeográfico e estatístico que estaba a realizar Pascual Madoz. Comeza tamén outro manuscrito titulado Álbum: poesía, asinado co pseudónimo de «Maiclar» xogando coas letras de Marcial—, que acollerá composicións de feitura romántica e sentimental coma a titulada «A un paxariño», seguramente dirixido a dama santiaguesa C.V.A., con quinta na Ulla, a quen agora parece galantear.

1844: En xullo trasládase a Zamora para facerlle compaña ao pai, que fora nomeado Intendente desta provincia. Marcial ten neste intre 23 anos e na cidade leonesa pasará os seguintes seis anos durante os cales ocupará distintas vogalías e comisionados na Administración provincial, sempre ao abeiro do pai. A súa viaxe ata alí deixou como resultado un «Diario» que se conserva no manuscrito Memorias de familia que, xustamente, comeza a redactar agora, en parte estimulado pola lectura de biografías 
como a do escritor e político francés Alphonse de Lamartine. Co tempo, as Memorias de familia acabarán conformando dous grosos tomos nos que Valladares, nunha prosa coidada e intimista, vai relatando as súas reflexións e os aconteceres máis destacados da familia durante o século XIX. Daraas por rematadas en 1902 (Brea / Nogueira 2006).

1845: En abril incorpórase ao colexio de avogados de Zamora. No tempo de lecer realiza varias visitas ás vilas e cidades da contorna: Valladolid, Benavente, Salamanca, Toro, Tordesillas, Simancas... Estas viaxes aproveitaraas para consultar crónicas antigas nas bibliotecas e arquivos e recadar todo tipo de informacións históricas para o que logo será unha Crónica da cidade de Zamora, que agora dá comezo. Outra parte do seu tempo tamén a dedica a compoñer versos de tintura sentimental, tanto en galego coma en castelán: nalgúns estraña os antigos amores deixados en Galicia, noutros sublima xa os novos encontrados en terras zamoranas. Deste ano data «Suidades», unha das súas composicións máis celebradas. Dende a primavera, toda a familia volve reunirse en Zamora.

1846: Pasa a ocupar o cargo de Visitador da renda de papel selado, que deixara vacante o seu irmán Sergio, que regresa a Galicia. A finais de setembro viaxa a Madrid para ver os fastos que acompañaban o duplo casamento real de outubro: o da raíña Isabel II, que chegara á maioría de idade, e o da súa irmá a infanta Luísa Fernanda. Da súa visita ao cemiterio de San Isidro deixou constancia na súa composición en galego «A un cementerio en Madrid en día de difuntos». É nesta altura cando inicia a relación amorosa cunha dama zamorana, amiga de súa irma Avelina, chamada Catalina Fernández; a ela consagrará varios poemas neste tempo e tamén despois, unha vez de volta en Galicia e roto xa o compromiso entre eles.

1847: O seu pai encarga ao pintor Laureano Sanz os retratos a óleo de Marcial e de Sergio, que aínda actualmente penduran das paredes do casal de Vilancosta. Marcial tiña daquela 26 anos e tanto as súas irmás coma el volverán tomar clases de música. Marcial acabaría sabendo tocar o violín, a guitarra e algo o piano e, co tempo, mesmo compoñerá algunha mazurca e algunha polca.

1848: É nomeado pola raíña Vocal supernumerario do Consello administrativo de Zamora. A señardade polas terras nativas da Ulla comezan a abrollar nalgunha das composicións en galego desta época, como na titulada «Á miña aldea» e na que comeza por «Eu soñei noutronte á noite».

1849: Na primavera, coa reorganización do Liceo artístico y literario de Zamora será elixido o seu Secretario xeral; nel acabarán inscribíndose tamén as súas irmás Luísa, na sección de declamación, e Avelina e Isabel, na de música.

1850: A primeiros de xaneiro a familia Valladares deixa Zamora e regresa a Galicia, primeiro a Ourense, onde pai e fillo foran nomeados Gobernador civil e Conselleiro supernumerario, respectivamente. Non obstante, tras certas intrigas políticas, ambos cesan en marzo e toda a familia regresa a 
Vilancosta, onde se vai asentar definitivamente, pois o pai decide retirarse e pedir a xubilación.

Nun primeiro momento, Marcial auxiliará o pai en pequenas cousas no despacho de avogado e ocupará o posto de Secretario da Xunta parroquial de beneficencia. Tamén aproveitará este ano para elaborar un catá$\operatorname{logo}$ da nutrida biblioteca de Vilancosta, formada daquela por máis de 567 títulos (Fernández Castro 2015). Neles sobranceaban por número os de temas xurídico-administrativos, os relixiosos e os de literatura española e francesa, pero non só - Cervantes, Chateaubriand, Rosseau, Lamartine, Camoens...-; tampouco faltaban a Ortografía, o Dicionario e a Gramática da Real Academia Española, tamén a de Salvá, e libros de xeografía, de historia —as Historias de Galicia de Paadín e Verea Aguiar-, de cociña, de medicina, de caza —á que Valladares era moi afeccionado-; ou revistas como La Aurora de Galicia e Revista de Galicia. E certamente ocioso, aproveitará neste momento para comezar a anotar algunhas cántigas populares e as primeiras voces do que será logo o seu Diccionario, e mesmo para compor algunha peza musical. Quizais deste tempo sexa o seu manuscrito Recuerdos de la adolescencia; nel recolle catorce pezas melódicas con indicacións de como se bailan e a súa letra, maioritariamente en castelán, ben que hai tres en galego: as tituladas «A Raposa», «O señor padre Paulino» e «O Minguchiño».

1851: Valladares entra na trintena de anos e na primavera sabe da mala nova da rotura do compromiso con Catalina Fernández, que quedara en Zamora, o que o deixou moi afectado. Os afectos por ela poetizaríaos nunha pequena colección de composicións que se pecha co romance en castelán «Zamora tiene una flor», escrito xa en Vilancosta. As queixas por esa rotura non desexada aínda as volveu versificar, desta vez en galego, na composición «A $* * * *$ » (1853), en que repite o refrán «¿Qué è de ti agora, / meu ai ai ai?», no intre en que ten noticia de que o casamento será con outro.

Xa en agosto, visita Vilancosta o escritor e amigo da familia Antonio Neira de Mosquera, que andaba a recadar datos da contorna para as súas Monografías de Santiago. Durante algunhas xornadas acompañarao de excursión por varias paraxes da Ulla que o inspirarán para compoñer a súa celebrada «Á fonte do Pico-Sagro» e lembrar tamén a súa composición «Un recordo», escrita en Zamora. Neira de Mosquera editaraa en setembro no seu xornal santiagués El Eco de Galicia e vén constituír o primeiro poema en galego publicado de Valladares. Neste mesmo xornal tamén aparecerá a costumista «La rosquillera», en castelán, que recorda en tema e fasquía a titulada «A castañeira en Santiago».

1852: É elixido Deputado provincial en Pontevedra pola xurisdición de Tabeirós e así dá comezo a súa etapa de «home público» no goberno de Pontevedra, onde ocupara diferentes cargos nos próximos catorce anos. Este ano participa na Corona poético-musical ofrecida ao literato José Nicolás de Azara cun soneto en galego e tamén figura como subscritor da publicación SS.AA.RR. los serenísimos duques de Montpensier en Galicia, que 
editaran Zepedano e Neira de Mosquera con motivo da súa visita a Galicia; a «Corona poética» que pechaba a obra abríase cun poema dedicado aos infantes do seu irmán Sergio.

1854: Son tempos de tristeira e loito en Vilancosta, pois ás mortes repentinas en 1853 da súa irmá máis vella Jacoba e do seu marido veu sumarse en maio deste ano tamén a de súa nai dona Concepción e en marzo do seguinte outra máis, moi sentida e inesperada: a do seu irmán Sergio, con só 31 anos. En xuño, tras a subida ao poder dos progresistas, disólvense as Deputacións e Valladares cesa como Deputado provincial.

1855: Durante o chamado «Bienio progresista» Valladares permanecerá alleo á vida política, residindo permanentemente en Vilancosta. Principia agora a redactar os primeiros apuntamentos do que serán os seus Elementos gramaticais e conclúe o traballo histórico Crónica de la muy noble ciudad de Zamora, iniciado en 1845.

1856: Valladares é reposto no cargo na Deputación tras o fracaso do «Bienio progresista». No literario, vai participar cuns versos gozosos na publicación Novena á la Santísima Virgen de la Guía, patrocinada polo pai. Tamén recibe carta en Vilancosta de Antonio de la Iglesia, quen, sabedor por Pintos que poetizaba en galego, solicita a súa colaboración para unha futura antoloxía de poetas galegos que tiña en mente. Valladares remitiralle o manuscrito Composiciones gallegas, con seis poesías, algunhas das cales aparecerán a principios da seguinte década na Galicia. Revista Universal de este Reino e no Álbum de la caridad.

1857: É nomeado Individuo da Xunta provincial de Pontevedra para a Exposición de los productos agrícolas de la península, islas adyacentes y provincias de Ultramar, celebrada no outono en Madrid, na que obtería dúas mencións honoríficas. Remata agora o manuscrito de cadros costumistas de tipo autobiográfico titulado Escenas contemporáneas: Flora, o hasta donde llega una mujer, en castelán, que aínda segue inédita.

1858: En xuño volve saír electo Deputado provincial por Tabeirós, pero non chega a tomar posesión xa que en agosto é nomeado pola raíña Vogal vicepresidente do Consello administrativo de Pontevedra. En varias ocasións deberá ocupar interinamente o posto de Gobernador provincial, xa nese ano mesmo e logo tamén en 1861, 1862 e 1863.

En setembro participará na delegación encargada de representar a provincia pontevedresa na visita da raíña Isabel II a Compostela e, en novembro, será distinguido como Individuo de mérito da Sociedade Económica de Amigos do País de Santiago polo seu bo facer en pro da Exposición agrícola, industrial y artística de Galicia, que se celebrara en xullo na cidade. Amais de publicar no xornal da propia exposición o artigo «Dos palabras sobre la agricultura e industria agrícola de Galicia», el e mais súa irmá Avelina participaran tamén como expositores con mostras agrícolas que foran premiadas. 
1860: Neste tempo na Deputación en Pontevedra, Valladares será vogal de varias comisións e xuntas, como as de Beneficencia, de Instrución pública, do Ferrocarril, de Estatística — nesta moi louvado_-, ou de Agricultura. O seu labor como xestor público foille recoñecido en xuño por orde da SS.MM. co título de Xefe Honorario de Administración Civil.

1861: En agosto, sendo Gobernador civil interino en Pontevedra, actuou como Presidente dos Xogos Florais celebrados na cidade durante os cales pronunciou un erudito discurso de apertura. Nace este ano en Vilancosta Laurentino Espinosa Valladares, fillo de Bernardo e Luísa, que será o herdeiro do casal á morte de Marcial; e, tamén en Vilancosta, reciben o arcebispo compostelán García Cuesta con ocasión dunha visita pastoral pola bisbarra da Ulla. A familia Valladares xa conseguira noutras ocasións indulxencias do arcebispo.

De por parte, nas páxinas da Galicia. Revista Universal publícase a súa composición «Á Fonte do Pico-Sagro» e no ano seguinte a titulada «A***»; ambas figuraban no manuscrito de Composiciones gallegas.

1862: Antonio de la Iglesia escolma catro composicións súas en galego no «Mosaico» do antolóxico Álbum de la caridad, xurdido dos Xogos Florais celebrados na Coruña un ano antes. Tres xa foran publicadas noutras ocasións: «Á miña aldea», «Á fonte do Pico-Sagro» e «A***»; a outra é nova: «Suidades», que databa de 1845.

1864: En marzo falece o pai José Dionisio, a súa irma Segunda toma os hábitos no convento da «Enseñanza» en Santiago e casa a irmá máis nova Isabel. En outubro, ante as eleccións xerais para Deputados a Cortes de novembro, abandona anticipadamente o posto de Presidente do Consello administrativo en Pontevedra, que ocupaba dende xaneiro, e, logo da vitoria dos conservadores, retírase a Vilancosta xa con retentos de abandonar a súa carreira na Administración.

1865: En xuño, coa volta ao goberno do xeneral O' Donnell, regresa a Pontevedra para ocupar de novo diferentes cargos no Consello administrativo da provincia. Durante o verán, terá noticia de que Catalina Fernández está tomando os baños en Vilaxoán e, grazas á mediación das irmás, logrará un intercambio de cartas con ela nas que se confesan a tristura de que a súa relación non tivese un final feliz. Data agora un álbum musical manuscrito con melodías de cantigas titulado Ayes de mi País, dedicado ás irmás, que permaneceu inédito ata que foi editado por Do Pico Orxais e Rei Sanmartín (2010). Parte deste material —entre o que se atopa o cantar de pandeiro que logo se coñecerá como «A ruada»- e outras informacións enviarallas a Manuel Murguía, das que o historiador dá referencia na súa Historia de Galicia.

1866: En xullo regresa ao poder o xeneral Narváez, polo que, definitivamente, Valladares dimite do seus cargos en Pontevedra e retírase en setembro á casa familiar da Ulla. Ten 45 anos e alí, solteiro, xa vivirá permanentemente na compaña de dúas tías anciás, as súas irmás Avelina e Luísa esta co seu marido e o fillo Laurentino- - cun bo retiro polo seu traballo 
na Administración e unhas boas rendas herdadas por testamento do pai. Esta nova vida de «señorito de aldea» permitiralle entregarse case por completo ás súas afeccións eruditas e literarias no seu despacho que mira ao Ulla e ao Pico Sagro.

1867: Data o manuscrito Cantigueiro popular, que, amais de coplas, contén refráns, adiviñas, traducións e outras mostras populares, ademais dun limiar redactado en galego onde fai unha defensa da poesía popular. Permanecerá inédito como volume ata que unha parte del, as «Cantigas da Ulla», foi publicado pola Real Academia Galega en 1970 e xa despois, integramente e cun Apéndice, por Luna Sanmartín (2003) coincidindo co centenario da súa morte.

1868: Escribe Asela, novela en castelán aínda inédita. Pola súa vez, o seu nome figura na lista xeral dos subscritores da Corona fúnebre dedicada ao seu amigo o xeólogo e naturalista Antonio de Valenzuela, aínda que non participou con ningunha composición. Tamén lle remite a Saco Arce a poesía «Á fonte do Pico Sagro», que resultará ser unha das oito que o presbítero ourensán escolme na sección de «Poesías escogidas» da súa Gramática gallega.

1869: En xuño dá por finalizada unha primeira redacción do que será o seu Diccionario gallego-castellano, seducido, sen dúbida, polo ronsel que foran deixando outras obras simbólicas do «renacemento» que estaba a experimentar a lingua e a literatura galegas. Nesta altura, certamente, a súa obra vén ser o colofón dunha década na que se publican os Ensayos en dialecto berciano (1861) de Fernández Morales; tamén a Galicia. Revista Universal (1860-1865), o Álbum de la caridad (1862) co «Mosaico» de vates galegos e o Diccionario gallego-castellano (1863) de Rodríguez, todos tres grazas ao labor dos irmáns De la Iglesia; e seguidamente os Cantares gallegos rosalianos (1863), o Compendio gramatical (1864) de Mirás, a Historia de Galicia (1865) de Vicetto e tamén a de Murguía, a Gramática gallega (1868) de Saco Arce e, no mesmo ano, El habla gallega de Cuveiro. Así e todo, o volume coas carpetas manuscritas do seu dicionario pasaría a ocupar temporalmente a librería da biblioteca familiar, á beira dos autógrafos dos cantigueiros, poemarios e novelas que nese intre aínda permanecían inéditos.

1870: Próximo á cincuentena de anos e sentíndose xa preparado no lingüístico, tras a recollida folclórica e lexicográfica, e cunha certa experiencia xa como narrador en castelán, Valladares quererá contribuír a aquel renacemento literario acometendo un xénero aínda inexplorado en galego: o da novela. Así, data agora o manuscrito Majina, ou a filla espúrea, o «conto-noveliña» bilingüe que narra a historia sentimental desgraciada de Otilia e Salvio, coa orfandade como tema de fondo e un final inesperado e exemplarizante. Constitúe na historia da literatura galega a primeira novela galega moderna, ben que permanecerá inédita toda a década. A obra, seguindo a versión do manuscrito orixinal, sería editada por Tarrío, Roig-Rechou e Neira (1991) e logo por Fernández Salgado (2011). 
1875: Coincidindo coas celebracións do Ano Santo, son convocados en Santiago para finais de xullo os terceiros Xogos Florais. Entre os dez temas propostos, nas bases sinalábase que o premio de honor sería para o autor da mellor poesía escrita en galego sobre o tema «A Romaría». O premio quedaría deserto, aínda que se lle concedeu un accésit a José María Chao Ledo, presbítero de Vilalba. Descoñecemos se Valladares concorreu aos xogos, pero o certo é que ese ano compuxo un longo poema de 64 estrofas titulado «A romería a Santiago de Compostela». Onde si participou con mostras de té e viño de varias clases, e con mención honorífica, foi na Exposición regional agrícola e industrial y artística de Galicia, que tamén ese ano e na mesma Santiago promovera a Sociedade Económica de Amigos do País.

1876: Coñecida a publicación este ano do Diccionario gallego de J. Cuveiro, Valladares retomará a redacción do seu co fin de amplialo, ben que é certo que en ningún intre deixara totalmente de facelo. Alén disto, en xuño remítelle uns apuntamentos sobre a vida do pai José Dionisio a Vesteiro Torres —-só uns días antes de que este se suicidase-, sen dúbida destinados a un dos tomos da Galería de gallegos ilustres, biografía que finalmente non se publicou. Igualmente remitiu datos sobre o seu irmán Sergio ao seu paisano Álvarez Insua, quen anos despois publicará unha biografía del no seu xornal habaneiro El Eco de Galicia nun exemplar de 1883, aínda que vai datada deste ano.

1878: A familia Valladares recibe de Roma a credencial de bendición apostólica concedida polo Papa León XIII, e é agora tamén cando toma amizade co Catedrático de literatura Gumersindo Laverde Ruíz, mercé a que fora profesor do sobriño Laurentino na Universidade. Laverde facilitaralle máis dun cento de palabras para o dicionario e exercerá de valedor da obra ante os membros da Real Academia Española, entre eles o Marqués de Valmar; a este, Valladares acabará emprestándolle o manuscrito algún tempo, pois daquela andaba coa súa edición das Cantigas de Santa María.

1879: É ano de moitas angueiras literarias. Remata a primeira parte das Memorias de familia e data o manuscrito Catálogo de árboles de adorno, arbusto y flores, aínda inédito, alén de comezar un Apéndice ò Cantigueiro popular, no cal, en anos vindeiros, irá transcribindo novas cantigas, poemas populares, romances, refráns, trabalinguas, contos, composicións propias e outros materiais populares. Ademais, envíalle algúns cantares a Saco Arce, que anda a traballar nese intre na Literatura popular de Galicia (1881), e tamén adiviñas e coplas a Antonio Machado y Álvarez. Comeza tamén a colaborar co xornal El Eco de Galicia da Habana e coa revista La Ilustración Gallega y Asturiana, editada en Madrid, que dirixe na parte literaria Manuel Murguía. Durante os tres anos que dura esta publicación, as súas follas acolleran algúns poemas seus de feitura costumista que datan destes anos — «A...», «Inés fiando» ou «Quieta xesta¡Vaite cojo!»-, o artigo sobre ortografía «Del apóstrofo en la escritura gallega», sete epigramas, unha partitura musical dunha cantiga e a súa novela Majina. 
1880: Certamente, o Annus mirabilis da literatura galega, tras algunhas negociacións con Murguía, a finais de setembro comeza a publicarse en La Ilustración Gallega y Asturiana, en once entregas, Majina, ou a filla espúrea. Fóra publicitada na revista como «por completo gallega» polo lugar onde pasaba, polos costumes que describía, polos caracteres que xuntaba e pola lingua en que estaba escrita. E abofé, Majina é un relato ecléctico no que se cruzan elementos folletinescos, costumistas, románticos e folclóricos. Ademais, resulta un revelador documento sociolingüístico sobre a situación idiomática na Galicia da segunda metade do século XIX, pois os personaxes exprésanse en diferentes linguas e rexistros segundo a súa procedencia xeográfica e social. Por outra parte, en novembro recibe a boa nova de que foi nomeado Correspondente da Real Academia Española, candidatura inspirada por Laverde e proposta polo Marqués de Valmar. Alén disto, as máis do medio cento de adiviñas enviadas a Machado y Álvarez aparecen publicadas na obra deste titulada Colección de enigmas y adivinanzas.

1881: Un dos seus poemas máis populares, «A castañeira en Santiago», é un dos 37 poemas escolmados por Francisco Portela Pérez para a súa Colección de poesías gallegas. Chegado outubro, reclamaralle ao Marques de Valmar o exemplar do dicionario prestado, coa escusa de engadirlle máis voces e xa en novembro remitirá á Academia española unha «modesta» colección manuscrita que encabeza como Cántigas populares gallegas.

1882: Arredor da trintena de coplas populares da súa colección son publicadas por Francisco Rodríguez Marín ao longo dos cinco tomos dos seus Cantos populares españoles, imprentados entre 1882 e 1883 . Ademais, o seu sobriño Laurentino tamén se licencia en Leis, como era tradición na familia.

1883: O xornal El Eco de Galicia da Habana, editado polo estradense Álvarez Insua, imprime os seus poemas de temática costumista «Rosa e Sabela», «Nai e filla» e «Terriña por terra», inéditas ata daquela. Valladares viña colaborando co xornal dende os inicios da publicación: en 1879 aparecera del «Deálogo n'unha tertulia d'aldea» e unha ducia de epigramas, en 1880 a xa coñecida «Quieta gesta-Vaite cojo», en 1882 unha «Poesía popular» e o romance «Despropósitos», e en 1885 «Suidades», agora modificada nalgúns versos con respecto á versión do Álbum.

Alén disto, sempre en boas relacións co círculo rexionalista compostelán de tendencia católica e tradicionalista, colabora tamén coa publicación santiaguesa Galicia Católica, dirixida por E. Villelga, con «Romance» e «Unha tarde na Ulliña», composicións de reminiscencias lamartinianas polo ton reflexivo e moralista que proxecta na paisaxe. A primeiros de ano xa participara cun soneto en castelán na Corona fúnebre ao escritor Andrés Murais, falecido prematuramente a finais de 1882.

1884: A rogos de varias amizades, entre elas Laverde e Álvarez Insua, dá por fin a luz a principios de marzo o seu Diccionario gallego-castellano, que se imprenta primeiro como folletín do xornal católico El Libredón e logo 
en outubro nun volume nas prensas do Seminario Conciliar. Durante uns meses, de maio a outubro, Valladares trasladarase a Santiago para seguir de cerca a súa edición. Das 9300 voces que dicía conter a primeira versión de 1868 pasa a ofrecer agora un volume de 700 páxinas con arredor de 12000 entradas que conteñen moitos exemplos de uso, varios centos de cantigas populares e refráns e mesmo mostras literarias de autores contemporáneos, amais dun apéndice e un vocabulario científico de botánica en castelán. Tiráronse 1025 exemplares, deles 600 foron para o autor e 25 de papel de luxo. Foi o dicionario máis importante da súa época -e por varias décadas - , tanto pola cantidade de voces coma pola calidade da información que achegaba. É a obra que máis fama e respecto lle deu.

Por outra parte, durante este tempo, Valladares seguiu a enviarlle a Machado y Álvarez material folclórico variado que finalmente foi impreso no tomo IV da Biblioteca de las Tradiciones Populares Españolas titulado Folk-Lore Gallego. Miscelánea. Nel colabora o transcritor de Vilancosta con máis de seis ducias de cantares populares, sete poesías populares, un xogo de prendas, tres trabalinguas, dous contos, unha trintena de locucións e frases feitas, e varias descricións de supersticións e meiguerías. A Miscelánea servía de cartón de presentación da sociedade do Folk-Lore Gallego que, impulsada por Machado, e non sen polémica, acabaría presidindo a Condesa Pardo Bazán e con Valladares como un dos seus Socios de mérito dende marzo. Xa en novembro, Álvarez Insua dá a nova no habaneiro El Eco de Galicia da intención de volver publicar no xornal a novela Majina, o que finalmente non se pasou.

1886: Antonio de la Iglesia escolma algúns traballos seus de carácter folclórico no tomo III de El idioma gallego. Su antiguidad y vida, entre eles o conto «Bastián e Crispín» e algunhas outras mostras aparecidas xa na Miscelánea a maioría delas.

1887: Data un novo manuscrito de recolleita popular que titula Novo apéndice ò Cantigueiro popular, inédito ata que o publicou Bouza Brey (1957). Contiña máis de medio cento de coplas, unhas poucas anotadas en 1884 no Ribeiro, e tamén un grupo de cantigas dedicadas a Vilancosta de autoría propia. Este ano tamén recibe carta da Coruña do editor Andrés Martínez Salazar solicitando a súa colaboración para a Galicia. Revista Regional, que Valladares acepta coa condición de que nela non se inclúan ataques persoais, cuestións impías ou ofensivas á moral e os bos costumes. Iguales condicións de participación impón (só «cosas de humorismo no bufa») cando a finais de outubro Alfredo Brañas lle escribe intermediando para que apoie a Enrique Labarta Posse e o seu proxecto de publicación Galicia Humorística. Esta maneira de proceder pode servir de mostra do código ético e a maneira de ser e pensar de Marcial Valladares. Non obstante, isto non era novo, pois nalgunha ocasión xa sinalara que no seu cantigueiro non cabían as coplas «picantes ó coloradas», como el dicía. E ficou explícito no prólogo do seu Diccionario ao notar que incluíra cantigas «que a la moral no ofenden» e no feito de que para a súa edición en volume solicitara a licencia eclesiástica, rubricada 
por Antonio López Ferreiro, conforme a obra non encerraba nada contra a fe nin ofensivo á moral.

Aceptadas aquelas condicións, nos números de 1887 da Galicia. Revista Regional apareceron asinados por Valladares o artigo de fondo social «Emigración», un novo grupo de sete cantigas populares, dous epigramas tamén novos e unha colección de 671 refráns; e nos exemplares de 1888 , outra vintena de cantigas, un apéndice ao seu refraneiro, os artigos «Escritura gallega» e «Una reflexión» — nos que daba o seu parecer na polémica ortográfica dese ano sobre a representación do son fricativo prepalatal xordo [J] - e catro entregas da súa novela en castelán Los tres expósitos, que non se completou.

Por outra parte, co fin de celebrar as vodas de ouro sacerdotais do daquela pontífice León XIII, convocáronse varios actos, entre eles unha Exposición mundial no Vaticano con todos os agasallos recibidos con motivo do xubileu. Valladares non perdeu a ocasión e participou con outros escritores enviando a través do Marqués Montoliu un exemplar do seu Diccionario e asinando no prego dos doadores, no que facía constar a súa «satisfacción dulcísima» ao saber que o seu libro lle chegaría ao Papa e pasaría a engrosar a Biblioteca do Vaticano. E aínda o Diccionario lle deu outra satisfacción máis, pois tamén neste ano o académico Marcelino Menéndez Pelayo, a petición da Academia, realizaría un ditame favorable sobre a obra recoñecendo os meritorios servizos filolóxicos que podía prestar por recoller un léxico novo, enteiramente galego, tomado da oralidade.

Tamén a pedimento de Alfredo Brañas, Valladares remitirá una nota biobibliográfica de si mesmo para publicar no Diccionario Enciclopédico Hispano-Americano.

1888: Comeza a colaborar na Galicia Humorística de Labarta Posse. Non hai número en que non exista algo da súa autoría: oito contos en galego — «Bastián e Crispín» e «Os tres irmáns», xa publicados antes, e os novidosos «Un lobo obrigado a desempeñar varios oficios», «As fillas zarabetas», «O cazador e o lagarto», «Veliños», «As galiñas e o pavo» e «O señor e seu arrendatario»—, outros oito en castelán inéditos, tres composicións de temática popular-costumista —a xa coñecida «Rosa e Sabela», e os inéditos daquela «Bribonada» e «Os dous ratos»-, amais de cinco epigramas en dúas entregas. No exemplar de finais de xuño, Labarta dedicoulle un poema que constitúe a primeira biografía publicada sobre Valladares. Ia acompañado do coñecido gravado de Enrique Meyer, que copiaba a foto que para a ocasión fixera en abril no estudio do fotógrafo Chicharro da Rúa Nova santiaguesa. Don Marcial estaba para facer os 67 anos.

Os contos populares da Galicia Humorística servirían de fonte de reprodución para outros semanarios, sobre todo monolingües en galego de carácter popular, como os pontevedreses $O$ Galiciano e a súa continuación como $O$ Novo Galiciano, que reproduciron cinco deses relatos, e o ourensán $O$ Tío Marcos d'a Portela, que copiou catro. No dirixido por 
Lamas Carvajal, xa antes apareceran algúns poemas de temática costumista, parte da súa colección de refráns e algunhas cantigas populares xa aparecidas noutros xornais.

1889: Envíalle a Amador Montenegro unha nova versión do conto «Bastián e Crispín» para publicar n'A Monteira, o semanario rexionalista que dirixía dende Lugo; nas súas páxinas tamén aparecerá no ano seguinte en seis entregas a súa Colección de refráns, agora cun novo apéndice.

1891: No semanario pontevedrés El Obrero, que dirixía Rogelio Lois, publica Manuel Castro López unhas notas biográficas sobre o pai José Dionisio chegadas dende Vilancosta. Este mesmo artigo volverá ser publicado en xuño do ano seguinte nun exemplar de El Eco de Galicia de Bos Aires. Castro López será un dos editores que máis divulgue a vida e obra da familia durante esta década que principia.

Así mesmo, con motivo do traslado o 25 de maio dos restos mortais de Rosalía de Castro, dende o cemiterio de Adina a San Domingos de Bonaval, Valladares brindaralle os versos de ton popular «A Rousalía», facéndoo en nome dos labregos da Ulla. As oito cuartetas que forman a composición son unha das últimas creacións poéticas coñecidas, xunto á dialogada «Consellos dunha nai» e «Fin de romaría», todas tres recollidas no seu manuscrito do Apéndice ò Cantigueiro popular. A súa poesía en galego foi estudada por Ríos Panisse (2000) e editada en volume por Fernández Salgado (2003a).

Por outra parte, nunha carta remitida en novembro por Casto Sampedro dende Pontevedra solicítalle a súa colaboración para recadar melodías para a Colección de música popular gallega, que nese intre Sampedro se propuña iniciar e que acabaría sendo o Cancionero musical de Galicia (1942). Valladares, entrado xa na setentena de anos, respóndelle un mes despois laiándose de que se encontra vello e co pulso tremente, ademais de soidoso polo abandono que ve da música e danzas tradicionais e a súa substitución por outras alleas. Así e todo, canda a carta, acabará remitíndolle unhas «pobres melodías» que tiña recolleitas de antes e o texto da composición «O férvellas», que lle sentira ao cego do Carrio.

1892: O lento abandono da súa faceta como poeta déixalle agora máis tempo para os traballos que teñen que ver coa codificación do idioma e coa anotación de novas palabras para o seu dicionario. Así, vai acabar de redactar o texto Elementos de gramática gallega, que encetara aló por 1855, con tres obxectivos: xustificar a ortografía empregada no seu Diccionario, ofrecer un texto coas regras gramaticais accesible para os escolares e contribuír á gloria de Galicia. Non obstante, o texto quedará inédito ata 1970 en que se publicará coincidindo que ese ano se lle dedicou o Día das letras galegas. Viría ser a terceira gramática, un texto ponte entre os descritivos de Mirás e Saco Arce e o prescritivo de Lugrís Freire, xa na época das Irmandes da fala, no século XX.

1893: O bonaerense El Eco de Galicia de Castro López publica unha biografía relativamente extensa sobre el asinada coas siglas «A.M.S.»—cremos 
que Amador Montenegro Saavedra- Colabora tamén Valladares nalgún número da pontevedresa La Revista Popular cun poema en castelán e un epigrama en galego e comeza agora a súa relación epistolar con Manuel Leiras Pulpeiro, a quen lle consultará varios significados de palabras que aparecían nos refráns que Leiras publicara na Galicia. Revista Regional. O traballo de lexicógrafo nesta década final da súa vida chega mesmo a obsesionalo, pois decátase de que aínda lle restan moitos vocábulos por recoller e definir. Desde este ano traballa xa nun novo suplemento ao Diccionario, que seguirá ampliando ata 1896. Nunha carta de xuño dirixida a Martínez Salazar, Valladares, logo de comentarlle a súa opinión sobre a ortografía fonética, remarca que para el a prioridade para o galego nese intre era recoller por toda Galicia o maior número de voces, completar o dicionario e escribir moito e bo para vigorizar o idioma, e deixar a cuestión ortográfica para as xeracións futuras.

1896: Data o manuscrito titulado Nuevo suplemento al Diccionario gallegocastellano publicado en 1884, que quedou inédito ata que o deu a coñecer Ares García (1996). Contiña este novo suplemento máis de 2000 entradas. Algunhas palabras fóranlle achegadas por Amador Montenegro e Pardo Saavedra, de cando colaboraba n'A Monteira, e tamén por Leiras Pulpeiro. Con respecto ao médico e literato mindoniense, pola correspondencia entre eles sabemos que Leiras lle enviaba palabras e Valladares, en troca, modismos. Don Marcial ten neste intre 75 anos e confésalle ao mindoniense que lle falta pulso e vista, aínda que conserva a afección polas cousas da terra. Copia na propia carta máis dunha trintena de frases feitas que recollera na Ulla e coméntalle o seu medo a que pola idade non poida dar ás prensas o suplemento ao dicionario no que traballa, co perigo de que as voces galegas se perdan ou que acaben sendo substituídas innecesariamente por vocábulos casteláns.

Por outra parte, sempre interesado pola ortografía do galego, ensaiará unha ultima proposta de tipo foneticista, aínda que non transcendeu porque esas follas ficaron inéditas en Vilancosta. A proposta inspirábase na formulada para o español por Jimeno Agius que nesa altura circulou na prensa madrileña, non sen polémica. Foi dada a coñecer por García Ares (2004).

1897: Fai testamento a favor do sobriño Laurentino, coa condición de que quede en Vilancosta, como así será.

1898: En xuño de 1898 recibe carta de Alfredo Brañas en que lle solicita información literaria da época céltica para unha futura Historia da literatura galega que proxectaba redactar. Valladares remitiulle un amplo informe e escusouse de non poder facer máis por mor da súa idade, cumpridos xa os 77 anos. Entre o material enviado estaba un longo romance de asunto mariano que comezaba «Érase a filla dun Rei», que logo publicaría Losada Diéguez, sobriño-neto político de don Marcial, na revista Nós en 1927.

De por parte, en agosto, El Eco de Galicia de Castro López publica unha biografía súa. Noutros números deste ano aparecerán asinados por 
Marcial Valladares case medio cento de «Cántigas», ata daquela inéditas, e un poema e dous contos xa publicados noutras ocasións.

1899: Castro López recolle no anuario Almanaque gallego, que edita dende o ano anterior, uns premonitorios versos de Valladares titulados «Fin de romaría», que serán os últimos que publique. No mesmo exemplar figura tamén un poema da súa irmá Avelina titulado «En un Álbum»; no do ano 1898 xa aparecera unha biografía dela.

1902: Morre en marzo a súa «muy querida e insubstituíble» irmá Avelina, como escribiu nas Memorias, unha irreparable perda para el; con ela levaba convivindo na casa patrucial toda unha vida. E tamén agora o momento en que decide dar por rematadas as Memorias de familia logo serían retomadas polo sobriño Laurentino-, aínda que non os apéndices ao dicionario, pois este ano aínda comeza un novo caderno co título «Más voces gallegas».

1903: O 20 de maio a súa morte é chorada en Vilancosta. Xa a deixara poetizada ao xeito popular nesta copla:
En Vilancosta nacín
e nela penso morrer;
decote lle tuven lei
e xuro non lla perder.

Tiña don Marcial 81 anos, para facer case 82. O seu corpo sería soterrado na adro da igrexa de Berres. Moi sentido foi o recordatorio que lle dedicou o mesmo día do pasamento o seu veciño e tamén escritor Manuel García Barros, que se publicou no pontevedrés El Áncora. Pero outros moitos xornais de todas as partes de Galicia recolleron tamén necrolóxicas del: o santiagués Gaceta de Galicia, os lugueses El Regional e El Norte de Galicia, o ferrolán El Correo Gallego, o pontevedrés La Correspondencia Gallega, a revista Galicia Histórica, o bonaerense El Eco de Galicia... Tamén chegaron unha chea de cartas de pésame a Vilancosta, entre elas a de Martínez Salazar. Na carta de resposta a este, datada de xuño, o seu herdeiro Laurentino Espinosa ofrecíalle ao editor coruñés a obra completa do seu tío, por se a quería publicar. Na carta de resposta, Martínez Salazar escusa a negativa a adquirila porque xa daquela cesara a súa actividade na Biblioteca Gallega.

1970: Dedícaselle a Marcial Valladares o Día das letras galegas. Con ese motivo algúns dos manuscritos inéditos que aínda gardaban os andeis da biblioteca familiar de Vilancosta vén este ano a luz, como os Elementos de gramática gallega, grazas a Fundación Penzol e a Editorial Galaxia; ou a parte das «Cantigas d'a Ulla» do seu Cantigueiro popular, publicadas pola Real Academia Galega. Tamén sae por primeira vez nun volume a novela Maxina en edición de Carballo Calero, que foi así mesmo o redactor do traballo «O señor de Vilancosta. Loubanza de don Marcial Valladares Núñez no Día das Letras Galegas», que servía de homenaxe da Universidade compostelá. Igualmente, o propio 17 de maio todos os xornais galegos ofreceron páxinas especiais lembrando o homenaxeado. 
Ademais, ese día A Estrada acolleu os actos centrais organizados pola Real Academia Galega e pola corporación municipal que daquela presidía Mario Blanco - en 1957 dera a coñecer anacos das Memorias de familia nun artigo aparecido en La Noche- Os nomes de Marcial e Avelina Valladares pasarían a denominar unha rúa da vila e tamén se inauguraría un monolito de dedicatoria.

2003: O Concello da Estrada celebra o «Ano Marcial Valladares» coincidindo co centenario da súa morte. Realízanse varios actos e publícanse varios traballos sobre a súa obra, entre eles o Cantigueiro popular, en edición de Luna Sanmartín (2003), e o seu refraneiro, por Fernández Salgado (2003b).

2021: Celébrase o Bicentenario do seu nacemento.

\section{III.- CABO}

Neste traballo quixemos homenaxear a Marcial Valladares agora que se cumpren os douscentos anos do seu nacemento e, para iso, pareceunos unha boa idea redactar unha cronoloxía biobibliográfica sobre el a partir da revisión dos traballos xa existentes e da achega de novos datos recadados da prensa da época, o que veu redundar nun coñecemento máis integral deste autor e da súa obra, fundamental no Rexurdimento galego.

Nas páxinas precedentes recordamos a súa nenez na Ulla, a súa etapa de universitario en Santiago de Compostela que coincide co rexurdir da súa Academia literaria, os seus primeiros versos en galego de corte romántico, a súa colaboración no dicionario de Pascual Madoz, a súa estadía en Zamora como funcionario da Administración, o inicio da redacción das Memorias familiares, o matrimonio frustrado cunha dama de Zamora ou as súas novas angueiras literarias unha vez retornado a Galicia en 1850. Anotamos tamén os seus varios postos na Administración provincial de Pontevedra, a importancia da relixión na súa familia e a pegada que iso foi deixando no seu código moral, a súa presidencia como Gobernador civil dos Xogos Florais de Pontevedra, o seu desencanto coa política e o conseguinte retiro en 1866 á «casa grande» de Vilancosta con apenas 46 anos. Dende aquela, evocamos a súa sosegada vida de «señor de aldea» polas terras da Ulla, que sen dúbida favoreceu a dedicación case exclusiva ás súas afeccións literarias e de carácter erudito, e repasamos as súas contribucións dende o seu despacho de Vilancosta ao Rexurdimento, no que participa activamente. $\mathrm{O}$ seu abnegado labor cuantifícase nun dicionario, unha gramática, máis de medio cento de poesías en galego, varios textos narrativos, entre eles Majina, a primeira novela galega moderna, e unha nutrida colección de cantigas, refráns, música popular, adiviñas, contos... Tamén nos acordamos do seu nomeamento de Correspondente da Real Academia Española e tamén de Socio mérito do Folk-Lore Gallego, e fomos dando conta das súas relacións con outros literatos e eruditos do momento (Neira de Mosquera, Murguía, os irmáns de la Iglesia, Álvarez Insua, Machado y Álvarez, Saco Arce, Casto Sampedro, Martínez Salazar, Labarta Posse, Castro López, Alfredo Brañas...) e revisando 
a presenza do seu nome nas follas da prensa máis determinante do momento ( $E l$ Eco de Galicia - tanto no de Santiago, como no da Habana e no de Bos Aires-, Galicia Revista Universal, La Ilustración Gallega y Asturiana, Galicia Católica, El Libredón, Galicia. Revista Regional, Galicia Humorística, O Tío Marcos, O Galiciano, A Monteira A Gaita Gallega, A Tía Catuxa...) e en colectáneas como o Álbum de la caridad, a Colección de poesías gallegas, as «Poesías escogidas» que Saco Arce escolmou ao final da súa gramática ou algunha Coroa fúnebre. Xa nos limiares do século XX, demos a nova do seu pasamento en Vilancosta, un ano despois do da súa irmá Avelina.

En fin, este artigo de homenaxe completámolo coa bibliografía final manexada, que vai seguida dun anexo cun inventario cronolóxico de traballos de xornalistas e investigadores que coma nós tamén se viron atraídos pola vida e obra do «señor de Vilancosta».

\section{IV.- BIBLIOGRAFÍA}

Brea López, M./ Ma X. Nogueira Pereira (2006) «As Memorias de familia de Marcial Valladares», A Estrada. Miscelánea Histórica e Cultural 9, pp. 7-24.

Do Pico Orjais, J. L./I. Rei Sanmartín (2010) Ayes de mi Pais. O cancioneiro de Marcial Valladares, Baiona, Dos Acordes.

Fernández Castro, J. A. (2015) «Catálogo da biblioteca de don José Dionisio Valladares, efectuado polo seu fillo Marcial Valladares», A Estrada. Miscelánea Histórica e Cultural18, pp. 89-133.

Fernández Salgado, X. A. (2002) Marcial Valladares (1821-1903). Lingua, literatura e folclore. Tese de doutoramento. Universidade de Santiago de Compostela (versión en CD-Rom, Santiago de Compostela, Servicio de publicacións da Universidade).

Fernández Salgado, X. A (ed.) (2003a) Marcial Valladares. Poesía, Vigo, Xerais, pp. 7-116.

Fernández Salgado, X. A. (2003b) «A colección de refráns de Marcial Valladares», Tabeirós Terra XIII, A Estrada, pp. 9-16.

Fernández Salgado, X. A. (2005) Marcial Valladares. Biografía dun precursor no Rexurdimento galego, Pontevedra, Deputación Provincial.

Fernández Salgado, X. A. (ed.) (2011) Marcial Valladares. Majina, ou a filla espúrea, Santiago de Compostela, Sotelo Blanco.

Fernández Salgado, X. A. (2018) «Bibliografía completa (1842-2018) de Marcial Valladares», en A. Acuña et al. (eds.), Homenaxe a Ramón Gutiérrez, Vigo, Servizo de publicacións da Universidade.

Ferreirós Espinosa, C. (2018) O legado dos Valladares de Vilancosta, Santiago de Compostela, Xunta de Galicia. 
García Ares, Ma ${ }^{\text {a }}$ C. (1996) Nuevo suplemento al Diccionario Gallego-Castellano publicado en 1884. Memoria de licenciatura, Universidade de Santiago de Compostela. [Publicado posteriormente como Nuevo suplemento al Diccionario Gallego-Castellano publicado en 1884, en Cadernos de lingua, anexo 4. A Coruña, Real Academia Galega.]

García Ares, Ma . C. (2004) «A derradeira proposta ortográfica de Marcial Valladares», en R. Álvarez et al (eds.), A lingua galega, historia e actualidade. Actas do I Congreso Internacional, vol. II, Santiago de Compostela, Instituto da Lingua Galega / Consello da Cultura Galega, pp. 337-344.

Luna Sanmartín, X. (ed.) (2003) Marcial Valladares. Cantigueiro Popular, A Estrada, Fundación Cultural da Estrada.

Pena, Xosé Ramón (2014) «Marcial Valladares», en Historia da Literatura galega. De 1853 a1916. O Rexurdimento, vol. II, Vigo, Xerais, pp. 117-119.

Ríos Panisse, $\mathrm{M}^{\mathrm{a}}$ Carme (2000) «Os inicios do Rexurdimento. "Marcial Valladares"», en Galicia Literatura: Os Séculos Escuros. O século XIX, t. XXXI, A Coruña, Hércules de Ediciones, pp.193-198.

Tarrío, A./M. Neira/B. Roig-Rechou (eds.) (1991) Marcial Valladares. Maxina, Vigo, Xerais.

\section{Anexo: Cronoloxía de traballos biográficos sobre Marcial Valladares}

1843-1902: Memorias de familia por Don Marcial Valladares Licenciado en Jurisprudencia, 2 vols. [Manuscrito: vol. I: 1943-1979, vol. II: 1880-1902]

1888: Labarta, E. «Nuestros colaboradores: Marcial Valladares», Galicia Humorística 12, Santiago (30/6/1888), pp. 354-356.

1893: M-S, A. «Notas biográficas. D. Marcial Valladares», El Eco de Galicia 63, Bos Aires (20/7/1893).

1895: García Doriga, A. «Escritores gallegos: Marcial Valladares», La Revista Popular, Pontevedra, 105 (29/10/1895), pp. 5-6.

1898: El Eco de Galicia. «D. Marcial Valladares Núñez», Bos Aires, 246 $(20 / 8 / 1898)$.

1901: La Idea Moderna. «D. Marcial Valladares», Lugo (14/6/1901), p. 1.

1903: La Correspondencia Gallega. «Marcial Valladares», Pontevedra (20/5/1903).

1903: García Barros, M. «iLuto!», El Áncora, Pontevedra (23/5/1903).

1903: Gaceta de Galicia. Diario de Santiago. «Marcial Valladares», Santiago de Compostela, 112 (23/05/1903).

1903: El Regional. «Gallegos Ilustres: Marcial Valladares», Lugo (24/5/1903).

1903: El Correo Gallego. «Marcial Valladares», Ferrol (29/5/1903), p. 1. 
1903: El Eco de Galicia. «D. Marcial Valladares y Núñez», Bos Aires $(20 / 6 / 1903)$.

1903: El Norte de Galicia. «Necrológica. Marcial Valladares», Lugo, 694 (25/05/1903), p. 1.

1903: G. M., J. «Necrología. Don Marcial Valladares», Galicia Histórica. Santiago, 9 (5/1903), pp. 618-619.

1922: Molina Mera, M. [M. Amor Meilán] «Marcial Valladares», El Correo de Galicia, Bos Aires (06/01/1924), p. 3.

1936: Calveiro, A. V. «Marcial Valladares Núñez», Cultura Gallega 6, A Habana, 20/6/1936, 3-4.

1950: Bergueiro López, M. «Marcial Valladares visto literaria y politicamente», La Noche, Santiago (20/5/1950).

1950: Fraguas, Fraguas, A. «Colaboradores gallegos de Madoz», El Museo de Pontevedra, t. V, pp. 173-174.

1951: Lanza, F. «Valladares Núñez, (Marcial)», Dos mil nombres gallegos. Bos Aires, Ediciones Galicia del Centro Gallego, p. 308.

1954: Couceiro Freijomil, A. «Valladares Núñez, Marcial», Diccionario biobibliográfico de escritores, t. III. Santiago de Compostela, Bibliófilos Gallegos, p. 444.

1954: Porto Matalobos, J. «El escritor Marcial Valladares», La Noche, Santiago de Compostela (22/5/1954).

1955: Vicenta, M. de [Manuel Bergueiro López] «Un día en casa de Maiclar», Faro de Vigo, Vigo (20/5/1955).

1957: Blanco Torres, M. «Las 'Memorias' de Marcial Valladares», La Noche, Santiago de Compostela (26/6/1957).

1962: F.G., M. «Berres, Vilancosta y Marcial Valladares», El Pueblo Gallego, Vigo (28/7/1962), p. 13.

1970: Bouza-Brey, F. «Semblanza de Marcial Valladares», Boletín da Real Academia Galega, XXX/352, A Coruña, Real Academia Galega, pp. 430-437.

1970: Carballo Calero, R. O señor de Vilancosta. Loubanza de don Marcial Valladares Núñez no Día das Letras Galegas, Santiago de Compostela, Universidade.

1970: Dónega, M. «Un viaxe a Galicia do século XIX, narrado por D. Marcial Valladares Núñez», Grial 28, pp. 225-226.

1970: Bergueiro López, M. «Marcial Valladares», Faro de Vigo, Vigo (8/4/1970).

1970: Bergueiro López, M. «Semblanza Valladarista», Faro de Vigo, Vigo (7/5/1970). 
1970: El Pueblo Gallego. «Marcial Valladares. Biografía sencilla», Vigo (17/05/1970), p. 8.

1970: García-Bodaño, S. «Valladares na nosa concencia», El Correo Gallego, Santiago (17/5/1970).

1970: Laxe Brañas, A. «Perfil humán de Marcial Valladares», El Correo Gallego, Santiago (17/5/1970).

1987: G[ónzález] B[Lasco], L. «Valladares Núñez, Marcial», Gran Enciclopedia Gallega, t. 29. Santiago / Gijón, Silverio Cañada Editor, p. 230.

1995: Vilavedra, D. (coord.). «Valladares Núñez, Marcial», en Diccionario da literatura galega. I Autores. Vigo, Galaxia, pp. 588-589.

2002: Fernández Salgado, X. A. Marcial Valladares (1821-1903). Lingua, Literatura e Folclore. Tese de doutoramento. Santiago de Compostela, Universidade. [Publicada en CD-Rom, Santiago de Compostela, Universidade.]

2003: Blanco Valdés, J. L. «Lembranza de Marcial Valladares no centenario da súa norte», EDUGA: Revista Galega do Ensino 39, pp.145-158.

2003: Fernández Castro, J. A. «Breve contribución á biografía do señor de Vilancosta, Don Marcial Valladares Núñez (Berres, A Estrada 1821-1903)», A Estrada. Miscelánea Histórica e Cultural 6, pp. 137-154.

2003: Fernández Salgado, X. A. «Cen anos sen Marcial Valladares: retallos da vida e obra», A Trabe de Ouro 57, pp. 89-102.

2005: Fernández Salgado, X. A. Marcial Valladares. Biografía dun precursor no Rexurdimento galego. Pontevedra, Deputación Provincial.

2013: Fernández Salgado, X. A. «Valladares Núñez, Marcial», Diccionario Biográfico Español. Madrid, Real Academia de la Historia, 40-42.

2018: Ferreirós Espinosa, C. O legado dos Valladares de Vilancosta. Santiago de Compostela, Xunta de Galicia.

2018: Fernández Salgado, X. A. «Bibliografía completa (1842-2018) de Marcial Valladares», en A. Acuña / X.H. Costas / A. Iglesias (eds.), Homenaxe a Ramón Gutiérrez. Vigo, Servizo de publicacións da Universidade. 